\title{
Modeling the pelagic habitat of salmon off the Pacific Northwest (USA) coast using logistic regression
}

\author{
Hongsheng $\mathrm{Bi}^{1, *}{ }^{1}$, Rachel E. Ruppel ${ }^{1}$, William T. Peterson ${ }^{2}$ \\ ${ }^{1}$ Cooperative Institute for Marine Resources Studies, Oregon State University, and ${ }^{2}$ National Marine Fisheries Service, \\ Northwest Fisheries Science Center, Hatfield Marine Science Center, 2030 Marine Science Drive, Newport, Oregon 97365, USA
}

\begin{abstract}
Defining marine habitat use for Pacific salmon Oncorhynchus spp. is important for effective resource management because salmon production has been linked to ocean conditions in the Northeast Pacific. Towards that goal, Chinook O. tshawytscha and coho salmon O. kisutch populations were sampled off Washington and Oregon, USA, in June 1998 to 2005 along with habitat variables including temperature, salinity, water depth, and chlorophyll a concentration. Correlation analysis and stepwise logistic regressions were run to identify the physical and biological factors that predict the presence of Chinook and coho salmon. Low zero-catch probability was used to indicate used habitat. For all life history stages, zero-catch probability decreased with increased chlorophyll concentration and decreased depth. Temperature was a significant predictor variable for subyearling Chinook and yearling coho presence based on stepwise logistic regression. The size of used habitat showed large spatial and temporal variations, where more used habitat occurred off Washington and the Columbia River mouth than off Oregon. This pattern may relate to a wider shelf and greater primary production to the north. The largest amount of used habitat occurred in 2000 and 2003 for all 5 life history stages examined. Sea-viewing Wide Field-of-Sensor (SeaWiFS) satellite images indicated high chlorophyll concentration in that period.
\end{abstract}

KEY WORDS: Salmon · Habitat modeling $\cdot$ Logistic regression $\cdot$ Chlorophyll $a \cdot$ Depth $\cdot$ Temperature Salinity $\cdot$ Fisheries

Resale or republication not permitted without written consent of the publisher

\section{INTRODUCTION}

Knowledge of marine habitat selection is essential for effective management of Pacific salmon Oncorhynchus spp. because nearly one-half of the total estimated salmon mortalities occur in marine and freshwater habitats alike (Bradford 1995). Changes in ocean conditions also cause large spatial and temporal variations for Pacific salmon production (Pearcy 1992, Mantua et al. 1997). Studies have shown that early summer upwelling off the Oregon and Washington, USA, coast may influence the growth rate of juvenile coho salmon (Fisher \& Pearcy 1988, Beamish \& Mahnken 2001, Logerwell et al. 2003). Characterizing salmon ocean habitat will enhance our understanding of how salmon marine survival, growth, and production are related to changes in ocean conditions.
The ocean conditions off the northwest coast of the USA have changed dramatically in recent years. After a rapid transition from the strong El Niño event in 1997-1998 to the La Niña event in late 1998-1999, strong coastal upwelling was observed until the end of summer 2002, when the Pacific Decadal Oscillation (PDO) index switched from positive to negative (Peterson \& Schwing 2003). In the same study, they reported enhanced copepod biomass and higher coho and Chinook salmon production during this period (Peterson \& Schwing 2003). From October 2002 through September 2005, a positive PDO index was observed, which indicates weak upwelling events and warm ocean conditions (Mantua et al. 1997). Shifts in large-scale climate processes could affect local oceanic structures, and may ultimately be reflected by changes in upper trophic levels of the local ecosystem (Francis \& Hare 1994). 
Changes in local environmental variables, such as temperature, salinity, and primary production, could have significant effects on both Chinook Oncorhynchus tshawytscha and coho salmon $O$. kisutch, as they are primarily coastal migrant species (Beamish et al. 2005). Temperature could influence salmon production off the Pacific Northwest (Cole \& Villacastin 2000), because it can regulate salmon growth rate (Hinch et al. 1995) and mortality (Friedland 1998). Sea surface temperature can delineate a sharp distributional boundary for salmon (Welch et al. 1998, Hinke et al. 2005). Variation in salmon production was related to variation in primary production in the North Pacific (Shiomoto et al. 1997). Furthermore, chlorophyll a concentration was reported to be significantly correlated with juvenile Chinook (age 1.0) distribution (Brodeur et al. 2004).

Many studies have attempted to understand the effects of environmental variability on salmon population dynamics; however, without knowledge of how individual species select and utilize their habitats, the question can not be fully answered. For example, adult Chinook salmon were shown to use 9 to $12^{\circ} \mathrm{C}$ water $52 \%$ of the time (Hinke et al. 2005). The area of the coastal ocean with temperatures in this range could show large spatio-temporal variations due to coastal upwelling, and may result in changes in utilized habitat that may impact Chinook salmon production.

In this study, we attempted to understand the Chinook and coho salmon population variability from a habitat perspective. As part of a series of studies, we first defined the ocean habitat characteristics for different life stages of Chinook and coho salmon based on presence and absence information using samples collected in June 1998 to 2004 off the Washington-Oregon coast. We also hypothesized that the size and location of useable habitat varies due to large-scale climate variability.

Logistic regression has become an increasingly popular tool in freshwater habitat studies (Knapp \& Preisler 1999, McHugh \& Budy 2004, Turdeon \& Rodriguez 2005). Due to the excessive number of zeroes and presence of a few extreme values in marine fishery survey data, i.e. lack of normality and homogeneous errors, logistic regression has the potential to describe marine fish habitat by converting abundance to presence/absence data. Using this methodology, the probability of presence/absence can be predicted as a function of one or more independent variables (Hosmer et al. 1988). Our method was designed to quantify habitat use for Chinook and coho salmon using a combination of different environmental factors.

The objectives of this study were to: (1) quantify habitat use for different life stages of Chinook and coho salmon as reflected in presence/absence data; (2) develop predictive models to identify used habitat; and (3) evaluate spatial and temporal variations of used habitat.

\section{MATERIALS AND METHODS}

Study site and sampling. Chinook and coho salmon were sampled along 10 transect lines off the Washington and Oregon coast in June 1998 to 2005 (Fig. 1). The transects sampled varied somewhat for the 8 cruises used to survey salmon catch in this study (Table 1). Each transect consisted of 6 to 8 stations extending from the shallowest trawlable water depth $(\sim 30 \mathrm{~m})$ to $50 \mathrm{~km}$ offshore. A Nordic 264 pelagic rope trawl manufactured by NET systems $30 \mathrm{~m}$ (wide) $\times 20 \mathrm{~m}$ (high), $100 \mathrm{~m}$ length, and a cod-end liner of $95 \mathrm{~mm}$ stretch mesh was used to collect salmon. For each tow, the trawl was towed at the surface at a speed of $\sim 6 \mathrm{~km} \mathrm{~h}^{-1}$ for $30 \mathrm{~min}$. Abundance was calculated as

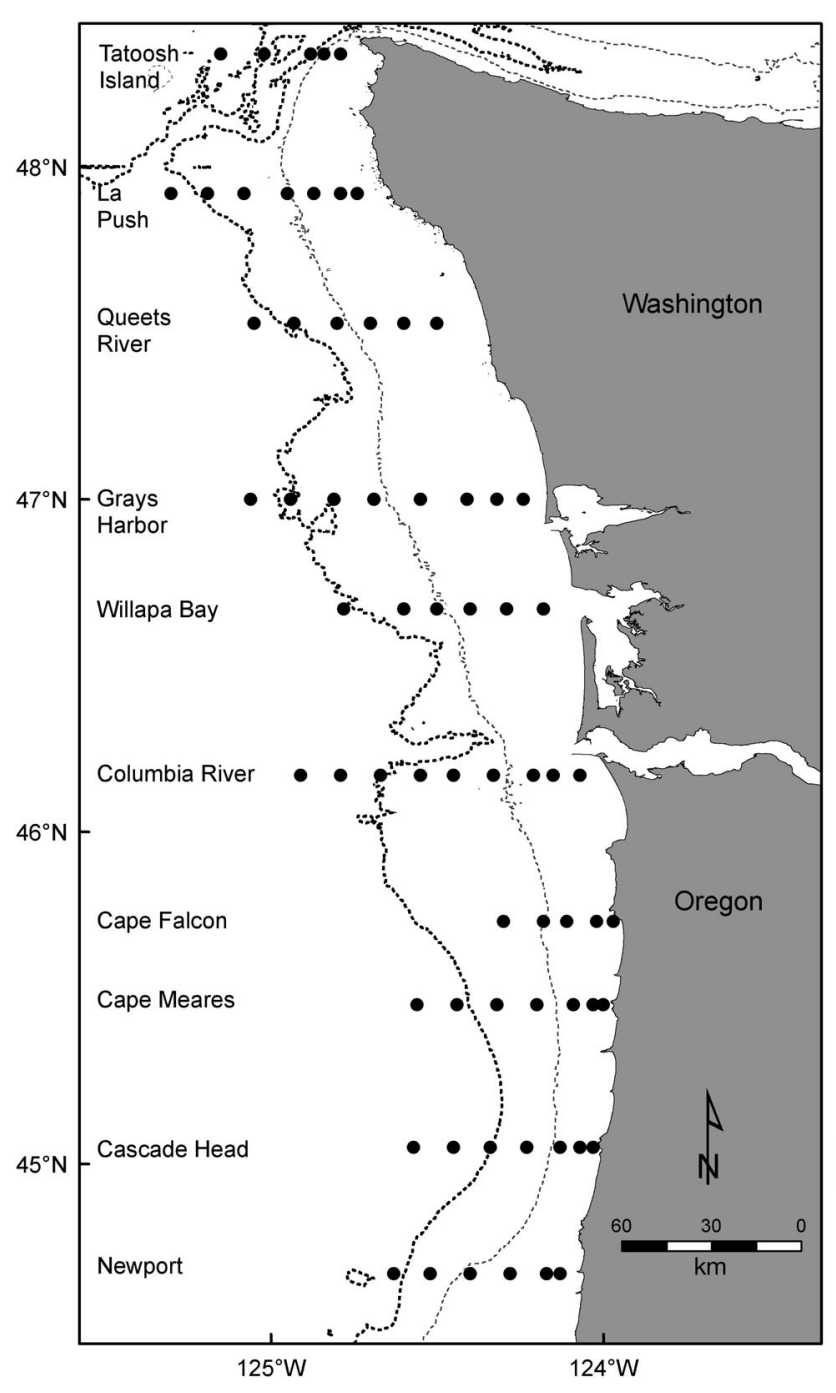

Fig. 1. Sampling stations along transects off the Washington and Oregon coasts sampled in June 1998 to 2005. The thin and bold dotted lines indicate $100 \mathrm{~m}$ and $200 \mathrm{~m}$ depth contours, respectively 
Table 1. Sampled transect lines and number of sampled stations along each line in June 1998 to 2004. CF: Cape Falcon; $\mathrm{CH}$ : Cascade Head; CM: Cape Meares; CR: Columbia River; GH: Grays Harbor; LP: LaPush; NH: Newport; QR: Queets River; TI: Tatoosh Island; WB: Willapa Bay

\begin{tabular}{|c|c|c|c|c|c|c|c|c|c|c|c|}
\hline & CF & $\mathrm{CH}$ & $\mathrm{CM}$ & CR & $\mathrm{GH}$ & LP & $\mathrm{NH}$ & QR & TI & WB & Total \\
\hline 1998 & 0 & 0 & 2 & 5 & 3 & 0 & 3 & 0 & 0 & 5 & 18 \\
\hline 1999 & 5 & 4 & 8 & 11 & 7 & 9 & 4 & 0 & 0 & 2 & 50 \\
\hline 2000 & 0 & 0 & 5 & 7 & 5 & 4 & 5 & 0 & 0 & 0 & 26 \\
\hline 2001 & 0 & 7 & 6 & 7 & 6 & 6 & 5 & 5 & 0 & 5 & 47 \\
\hline 2002 & 0 & 6 & 5 & 8 & 6 & 3 & 5 & 6 & 0 & 6 & 45 \\
\hline 2003 & 0 & 7 & 7 & 10 & 5 & 6 & 7 & 6 & 5 & 6 & 59 \\
\hline 2004 & 0 & 5 & 6 & 7 & 7 & 6 & 6 & 6 & 0 & 5 & 48 \\
\hline Total & 5 & 29 & 39 & 55 & 39 & 34 & 35 & 23 & 5 & 29 & 293 \\
\hline
\end{tabular}

number of fish caught divided by distance towed $(\mathrm{km})$ and net width.

Temperature and salinity profiles were measured with a CTD at each station to either $100 \mathrm{~m}$ depth or within $5 \mathrm{~m}$ of the bottom. We used temperature and salinity at a depth of $3 \mathrm{~m}$ in this analysis. Chlorophyll a samples were collected at $3 \mathrm{~m}$ depth using a Niskin bottle and water filtered through a GF/F filter. Chlorophyll a concentration was calculated from fluorescence measurements using a Turner Designs 10-AU fluorometer following a standard acetone extraction procedure (Arar \& Collins 1997).

We used 293 fish samples along with temperature, salinity, depth, and chlorophyll a collected during June of 1998 to 2004, as described by Brodeur et al. (2005), to build predictive models for suitable salmon habitat. We used 38 samples collected in June 2005 as independent samples to validate the selected models. Chinook salmon were classified into 3 life history stages: juvenile subyearling Chinook (or 'ocean-type', spending less than $1 \mathrm{yr}$ in freshwater), juvenile yearling Chinook (or 'stream-type', spending $1.5 \mathrm{yr}$ or more in freshwater), and subadult Chinook (those that have been at sea for at least $1 \mathrm{yr}$ ). Coho salmon generally exhibit a 3 yr life history, with $1.5 \mathrm{yr}$ in freshwater and $1.5 \mathrm{yr}$ in saltwater. They were classified as yearling coho (first summer at sea) and subadult coho (second summer at sea).

Data analysis. To identify the factors that were significantly associated with the abundance of the 5 life history stages, we computed correlation coefficients between each individual environmental factor and the abundance of each life history stage of Chinook and coho salmon. We chose nonparametric Spearman correlation coefficients because of the lack of normality in the data that could not be corrected through transformation. Environmental variables included temperature, salinity, chlorophyll $a$ and depth. The hypotheses that each of the 4 variables was not correlated with salmon abundance were tested using $t$-tests at the $95 \%$ significance level (CORR procedure in SAS 9.1).

We converted salmon abundance data to binary data (presence/absence) because there were no clear relationships between salmon abundances and temperature, salinity, chlorophyll $a$ and depth. We used presence data as the response variable and the same 4 environmental factors as predictor variables to run a series of logistic regression models (Eq. 1):

$$
P(y=0 \mid X)=\frac{\exp \left(\beta^{\prime} X\right)}{1+\exp \left(\beta^{\prime} X\right)}
$$

where $X=\left(1, x_{1}, \ldots, x_{k}\right)^{\prime}$ is a vector holding environmental variables measured at sampled stations, $\beta^{\prime}=\left(1, \beta_{1}, \ldots, \beta_{k}\right)$ is a vector of coefficients, $k$ is the number of environmental variables, $P$ is zero-catch probability and $y$ is the binary response variable (presence/absence).

Models were selected for the different life history stages of Chinook and coho salmon using stepwise selection, an approach that allowed both addition and deletion of variables. A significance level of $85 \%$ was specified to allow a variable into the model, and a significance level of $90 \%$ was specified for a variable to stay in the model. The final model included variables that were significant at $95 \%$ at the last stepwise selection step. Hosmer and Lemeshow goodness-of-fit tests (Hosmer et al. 1988) were performed for the final selected models. We used $\chi^{2}$ tests at the $95 \%$ significance level to test whether coefficients for all environmental variables were equal to zero (LOGISTIC procedure in SAS 9.1.3, SAS Institute, 2005).

The logistic regression model was used to predict the chance of presence or absence of Chinook and coho salmon based on the set of selected variables in the final models. In this study, we predicted the zero-catch probability for each sampling station, with a high probability of zero catch indicating non-used habitat and low probability of zero catch indicating used habitat. We also used nonparametric interpolation to map spatial patterns (thin plate spline interpolation procedure in ArcGIS 9.0, ESRI, 2004).

We used data collected in June 2005, which was not included in the model selection procedure, to validate the selected models. We first predicted the zero-catch probability for each life history stage using selected models and compared the results with presence/ absence in the field. To evaluate the accuracy of model predictions, we converted the probability of zero catch to presence/absence data (breakpoint at 0.5 probability) and calculated accuracy for each class. The accuracy of presence/absence data was the percentage of correctly predicted stations out of all stations where fish were caught/not caught. In addition, we calculated the overall accuracy of the model, or the percentage of correctly predicted stations out of all stations. 


\section{RESULTS}

\section{Nonparametric correlation}

Abundance of all 5 life history stages was positively correlated with chlorophyll a concentration and negatively correlated with water depth (Table 2). Temperature was negatively correlated with yearling and subadult Chinook and subadult coho. Salinity only had a significant correlation with subadult coho (Table 2).

Table 2. Oncorhynchus tshawytscha and O. kitsutch. Nonparametric Spearman coefficients among salmon abundance at each life history stage and 4 environmental variables. Total observation number is 293 , and the significance level is $95 \%$. Significant values in bold. Note that small coefficients at significant levels indicate small effects

\begin{tabular}{|lccccc|}
\hline $\begin{array}{l}\text { Species and } \\
\text { stages }\end{array}$ & Statistics & $\begin{array}{c}\text { Temperature } \\
\left({ }^{\circ} \mathrm{C}\right)\end{array}$ & $\begin{array}{c}\text { Salinity } \\
(\mathrm{psu})\end{array}$ & $\begin{array}{c}\text { Chlorophyll } \\
\left(\mathrm{mg} \mathrm{m}^{-3}\right)\end{array}$ & $\begin{array}{c}\text { Depth } \\
(\mathrm{m})\end{array}$ \\
\hline Chinook & & & & & \\
Subyearling & Coefficient & -0.07 & -0.07 & 0.39 & -0.29 \\
& $\mathrm{p}$ & 0.23 & 0.25 & $<\mathbf{0 . 0 1}$ & $<\mathbf{0 . 0 1}$ \\
Yearling & Coefficient & -0.17 & -0.07 & 0.45 & -0.46 \\
& $\mathrm{p}$ & $<\mathbf{0 . 0 1}$ & 0.26 & $<\mathbf{0 . 0 1}$ & $<\mathbf{0 . 0 1}$ \\
Subadult & Coefficient & -0.36 & 0.05 & 0.59 & -0.51 \\
Coho & $\mathrm{p}$ & $<\mathbf{0 . 0 1}$ & 0.44 & $<\mathbf{0 . 0 1}$ & $<\mathbf{0 . 0 1}$ \\
Yearling & Coefficient & -0.04 & $<0.01$ & 0.21 & -0.12 \\
Subadult & $\mathrm{p}$ & 0.50 & 0.92 & $<\mathbf{0 . 0 1}$ & $\mathbf{0 . 0 4}$ \\
& Coefficient & -0.40 & 0.15 & 0.64 & -0.43 \\
& $\mathrm{p}$ & $\mathbf{< . 0 1}$ & $\mathbf{0 . 0 1}$ & $\mathbf{< 0 . 0 1}$ & $<\mathbf{0 . 0 1}$ \\
\hline
\end{tabular}

Table 3. Oncorhynchus tshawytscha and O. kitsutch. Results of stepwise model selection from logistic regression models. Hosmer and Lemeshow (HL) goodnessof-fit was tested using $\chi^{2}$ with $\mathrm{df}=5$. A p-value $>0.05$ for the HL test indicates no evidence of lack of goodness-of-fit

\begin{tabular}{|lcccccr|}
\hline $\begin{array}{l}\text { Species and } \\
\text { stages }\end{array}$ & Statistics & Intercept & $\begin{array}{c}\mathrm{Chl} \mathrm{a} \\
\left(\mathrm{mg} \mathrm{m}^{-3}\right)\end{array}$ & $\begin{array}{c}\text { Depth } \\
(\mathrm{m})\end{array}$ & $\begin{array}{c}\text { Temperature } \\
\left({ }^{\circ} \mathrm{C}\right)\end{array}$ & $\begin{array}{r}\mathrm{HL} \\
\text { test }\end{array}$ \\
\hline Chinook & & & & & & \\
Subyearling & Coefficient & 3.90 & -0.13 & $0.44 \times 10^{-2}$ & -0.22 & \\
& $\chi^{2}$ value & 7.56 & 13.99 & 4.76 & 4.55 & 11.97 \\
& $\mathrm{p}$ & $<0.01$ & $<0.01$ & 0.03 & 0.03 & 0.15 \\
Yearling & Coefficient & -0.08 & 0.14 & $0.54 \times 10^{-2}$ & & \\
& $\chi^{2}$ value & 0.08 & 14.12 & 9.07 & & 10.40 \\
& $\mathrm{p}$ & 0.78 & $<0.01$ & $<0.01$ & & 0.24 \\
Subadult & Coefficient & -0.55 & -0.20 & $2.34 \times 10^{-2}$ & & \\
& $\chi^{2}$ value & 1.81 & 23.41 & 32.14 & & 6.60 \\
& $\mathrm{p}$ & 0.18 & $<0.01$ & $<0.01$ & & 0.58 \\
Coho & & & & & & \\
Yearling & Coefficient & 3.50 & -0.10 & $0.46 \times 10^{-2}$ & -0.31 & \\
& $\chi^{2}$ value & 7.31 & 7.36 & 12.16 & 10.65 & 11.14 \\
& $\mathrm{p}$ & $<0.01$ & $<0.01$ & $<0.01$ & $<0.01$ & 0.19 \\
Subadult & Coefficient & 0.82 & -0.36 & $1.19 \times 10^{-2}$ & & \\
& $\chi^{2}$ value & 3.62 & 40.64 & 11.21 & & 10.16 \\
& $\mathrm{p}$ & 0.06 & $<0.01$ & $<0.01$ & & 0.25 \\
& & & & & & \\
\end{tabular}

\section{Model selection}

Chlorophyll a concentration and water depth were models for all 5 life history stages as indicated by the Hosmer and Lemeshow tests (Table 3).

The zero-catch probability for all 5 life history stages decreased as chlorophyll a concentrations increased, i.e. there was a greater chance of catching a Chinook or coho salmon in areas with high chlorophyll a concentration (Table 3). The zero-catch probabilities for all 5 life history stages decreased exponentially with chlorophyll a concentration (Fig. 2). For subyearling and yearling Chinook and subadult coho, stations with low zerocatch probability were restricted to high chlorophyll $a$ areas more than so for subadult Chinook and yearling coho. For example, stations with zerocatch probability lower than 0.2 for yearling Chinook generally had higher chlorophyll a concentrations (> $\sim 8$ to $26 \mathrm{mg} \mathrm{m}^{-3}$, Fig. 2B), whereas yearling coho had a much wider range of chlorophyll a concentration when zero-catch probability was lower than $0.2\left(\sim 4\right.$ to $26 \mathrm{mg} \mathrm{m}^{-3}$, Fig. 2D).

Zero-catch probability increased as water depth increased for all 5 life history stages, e.g. there was a higher probability of catching subyearling Chinook in shallow water than in deep water (Fig. 3, Table 3). Stations with zero-catch probability lower than 0.5 were those at $150 \mathrm{~m}$ water depth for subyearling and yearling Chinook and those at $100 \mathrm{~m}$ water depth for subadult Chinook and coho. Yearling coho had a wider distribution compared to other life history stages, such that stations with zero-catch probability lower than 0.5 occurred up to $200 \mathrm{~m}$ water depth (Fig. 3).

Zero-catch probability increased as temperature decreased for subyearling Chinook and yearling coho (Table 3). However, scatter plots for the predicted probability versus temperature did not show a clear trend (Fig. 4). 

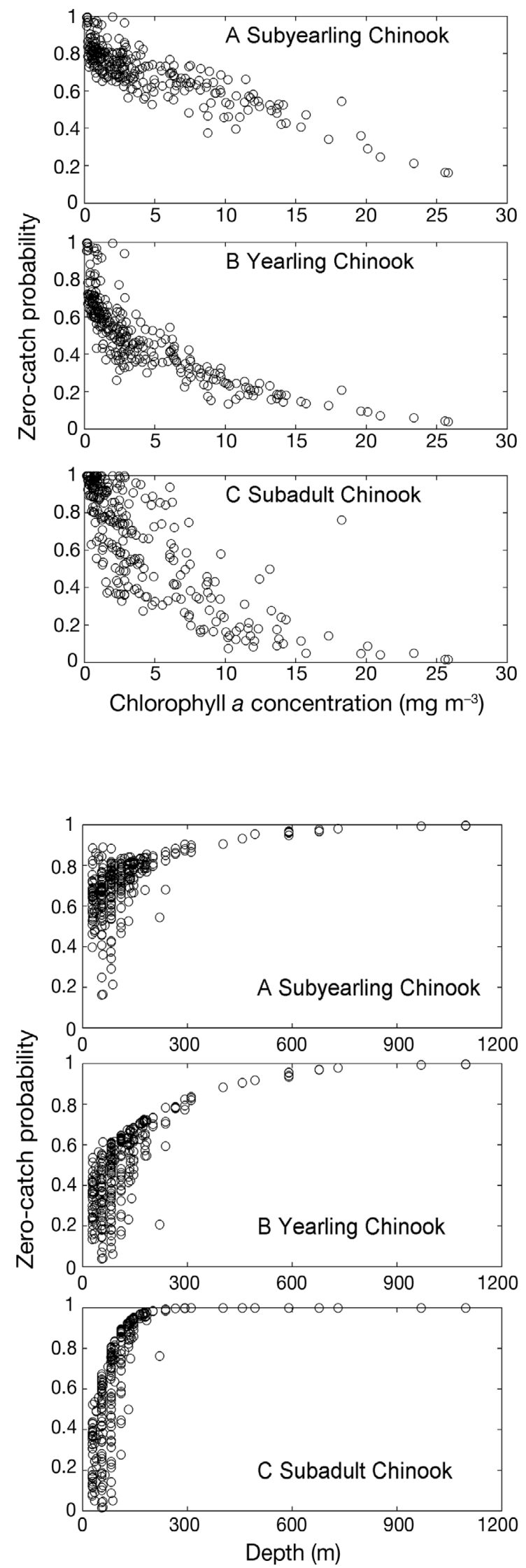

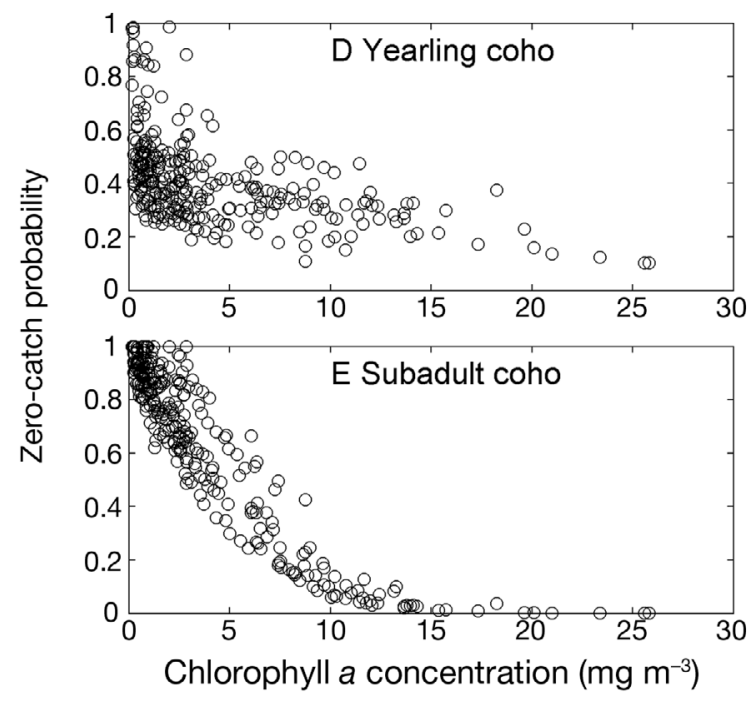

Fig. 2. Oncorhynchus tshawytscha and O. kitsutch. Chlorophyll a concentration and predicted zero-catch probability based on selected logistic regression models for all 5 history types: (A) subyearling Chinook; (B) yearling Chinook; (C) subadult Chinook; (D) yearling coho; and (E) subadult coho

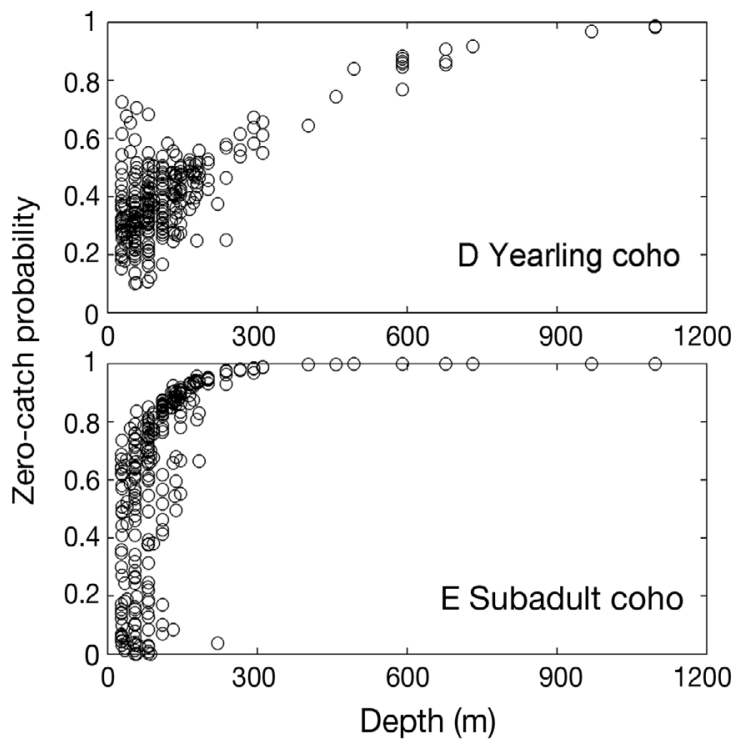

Fig. 3. Oncorhynchus tshawytscha and O. kitsutch. Water depth and predicted zero-catch probability based on selected logistic regression models for all 5 history types: (A) subyearling Chinook; (B) yearling Chinook; (C) subadult Chinook; (D) yearling coho; and (E) subadult coho 


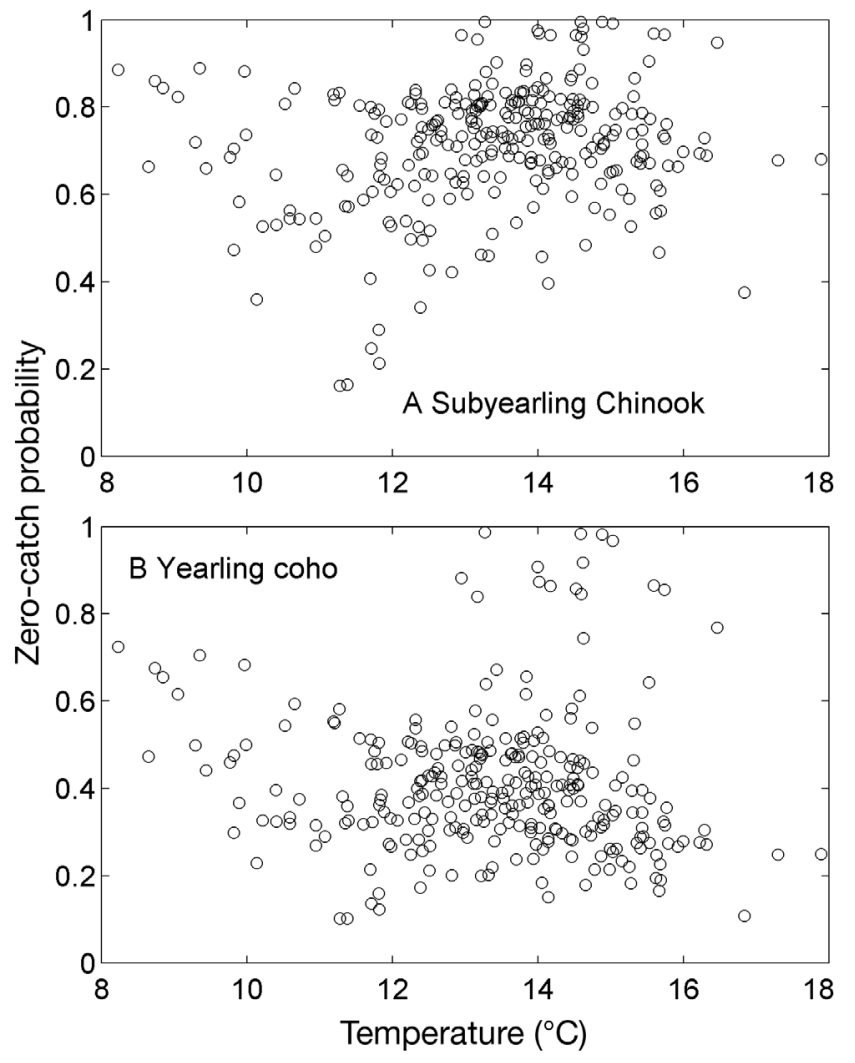

Fig. 4. Oncorhynchus tshawytscha and O. kitsutch. Temperature and predicted zero-catch probability based on selected logistic regression models. (A) Subyearling Chinook; (B) yearling coho

\section{Spatial variation}

Abundance of all 5 life history stages showed large spatial variation across 8 yr of study (see Figs. 5-9). Subyearling and subadult Chinook and subadult coho were caught at fewer than $50 \%$ of the sampled stations, whereas yearling Chinook and yearling coho were caught at more than $50 \%$ of the sampled stations (except 1998 and 2000). Most fish were caught from the north of the Columbia River: $99 \%$ of subyearling Chinook, $92 \%$ of yearling Chinook, $87 \%$ of subadult Chinook, $83 \%$ of yearling coho, and $76 \%$ of subadult coho. Eight-five percent of subyearling Chinook, $87 \%$ of yearling Chinook, $97 \%$ of subadult Chinook, and $97 \%$ of subadult coho were caught within $\sim 24 \mathrm{~km}$ from the shore, whereas $33 \%$ of yearling coho were caught within $\sim 24 \mathrm{~km}$ from the shore.

General spatial habitat patterns for subyearling Chinook were similar over the course of the study period such that zero-catch probabilities were relatively high for most of the study area, but were lower in coastal waters than offshore waters (Fig. 5). In 2000-2004, areas with low zero-catch probabilities $(p<0.5)$ were generally located at the mouth and to the north of the
Columbia River, with small areas off the Oregon coast having relatively low zero-catch probabilities. This pattern was also observed in abundance data, where subyearling Chinook were relatively more abundant near the mouth and the north of the Columbia River than at other stations (Fig. 5). In 1998 and 1999, predicted zero-catch probabilities were higher than $50 \%$ for the entire study area for subyearling Chinook and that was generally consistent with the catch data (subyearling Chinook were not caught at most stations).

Predicted zero-catch probabilities for yearling Chinook were lower in shallow coastal waters than in deeper water throughout the study period (Fig. 6). The region north of the Columbia River generally had a relatively larger area of a lower zero-catch probability $(<0.5)$ than the southern region. The largest area of predicted zero-catch probability $(<0.5)$ was found in 2003, with progressively smaller areas found in 1999, 2004, 2000, 2002, and 2001. In 1998, a relatively small area of low zero-catch probability was observed, though not all transects in the north were sampled.

Areas with low zero-catch probability for subadult Chinook were primarily in the shallow coastal waters (Fig. 7). This nearshore pattern was consistent throughout the entire study period. Relatively large areas with low zero-catch probability were found in 2000 and 2003. In 2000, these areas were mainly located to the north of the Columbia River, while in 2003, these areas extended south in a narrow strip along the central Oregon coast. In 2001, 2002, and 2004, these areas were narrower than in 2000 and 2003. In 1998 and 1999, the predicted zero-catch probability was less than 0.3 over the entire study area.

Areas with low zero-catch probability $(<0.5)$ for yearling coho were widely distributed along the Washington and Oregon coast (Fig. 8). However, the Washington coast generally had a larger area than the Oregon coast. The area of low predicted probability for yearling coho extended from shallow coastal waters to almost $200 \mathrm{~m}$ water depth. Areas of predicted probability lower than 0.2 were located primarily off Washington, with a few small areas off Oregon. The years 2000 and 2003 had the largest areas with probability less than 0.2, followed by 2001 and 2004.

Throughout the entire study period, areas of low predicted probability of zero catch for subadult coho $(<0.5)$ were located mainly in shallow coastal waters (Fig. 9). Most areas with low predicted probability were off the Washington coast and the Columbia River mouth, and included a few small areas that were off the central Oregon coast. The largest area with zerocatch probability lower than 0.2 was found in 2003, with successively smaller areas found in 2000, 2001, 2002, and 2004. In 1998 and 1999, the predicted probability was high in most areas. 

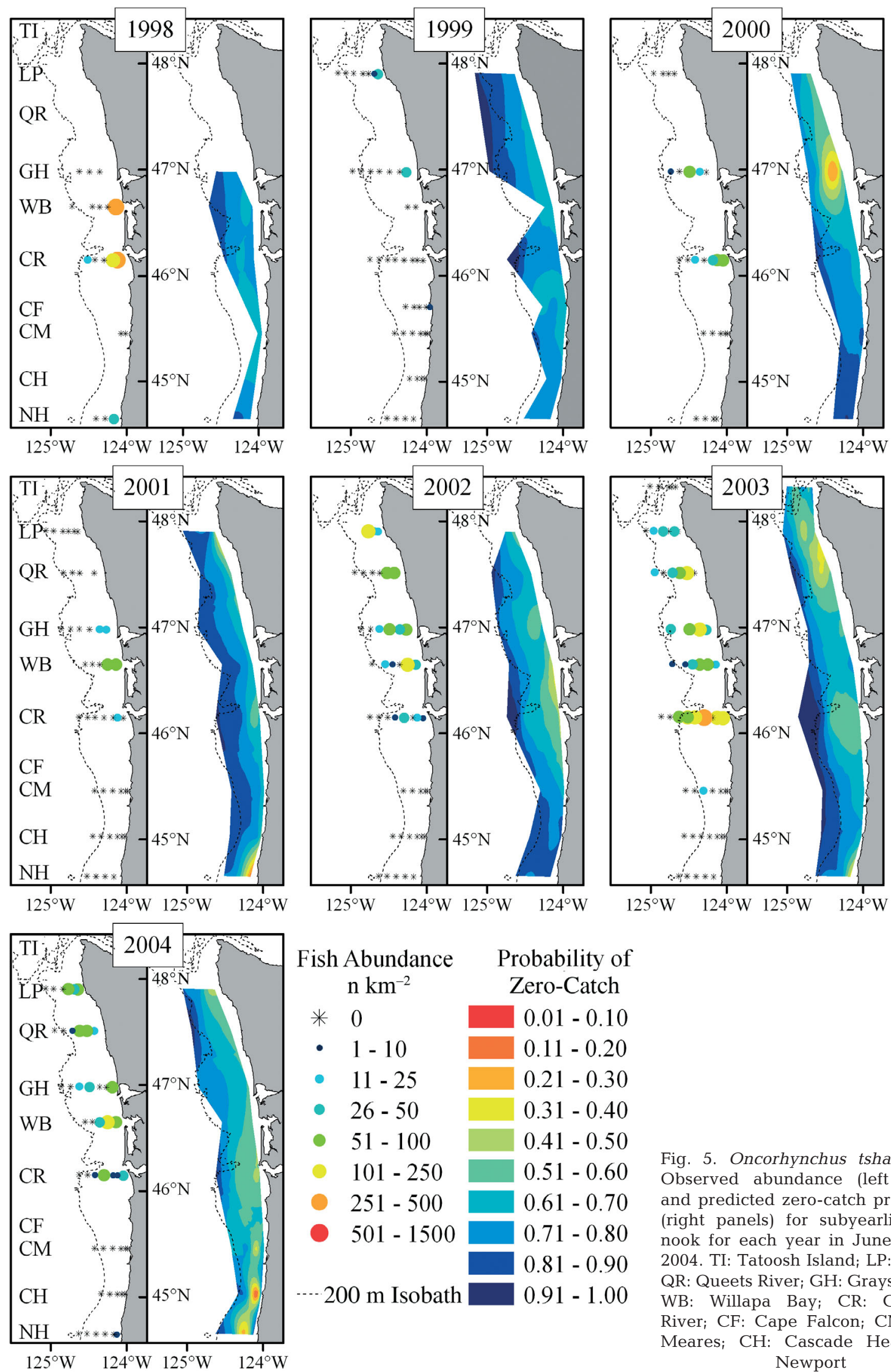

Fig. 5. Oncorhynchus tshawytscha. Observed abundance (left panels) and predicted zero-catch probability (right panels) for subyearling Chinook for each year in June 1998 to 2004. TI: Tatoosh Island; LP: LaPush; QR: Queets River; GH: Grays Harbor; WB: Willapa Bay; CR: Columbia River; CF: Cape Falcon; CM: Cape Meares; $\mathrm{CH}$ : Cascade Head; $\mathrm{NH}$ : Newport 

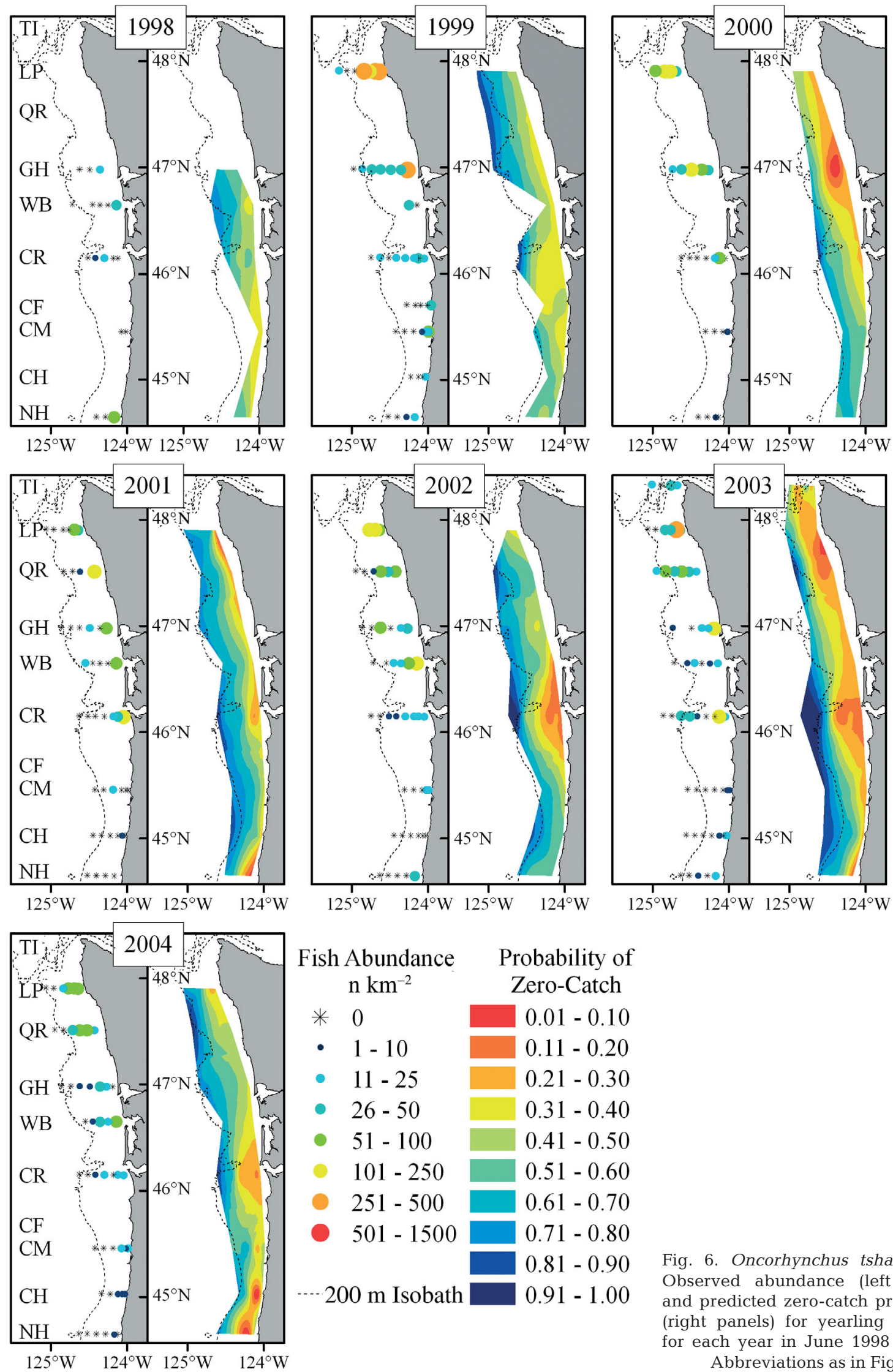

Fig. 6. Oncorhynchus tshawytscha. Observed abundance (left panels) and predicted zero-catch probability (right panels) for yearling Chinook for each year in June 1998 to 2004. Abbreviations as in Fig. 5 

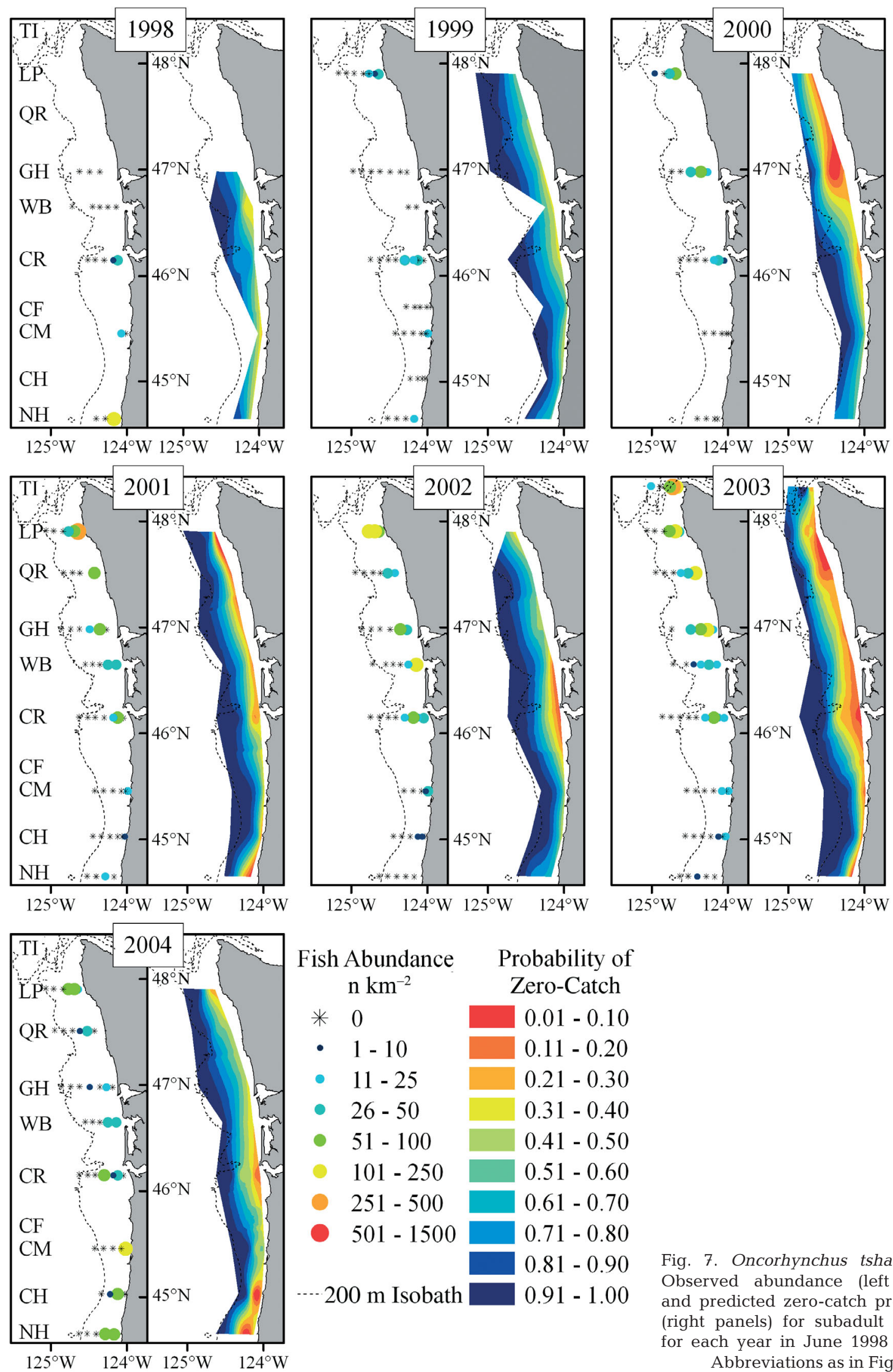

Fig. 7. Oncorhynchus tshawytscha. Observed abundance (left panels) and predicted zero-catch probability (right panels) for subadult Chinook for each year in June 1998 to 2004. Abbreviations as in Fig. 5 

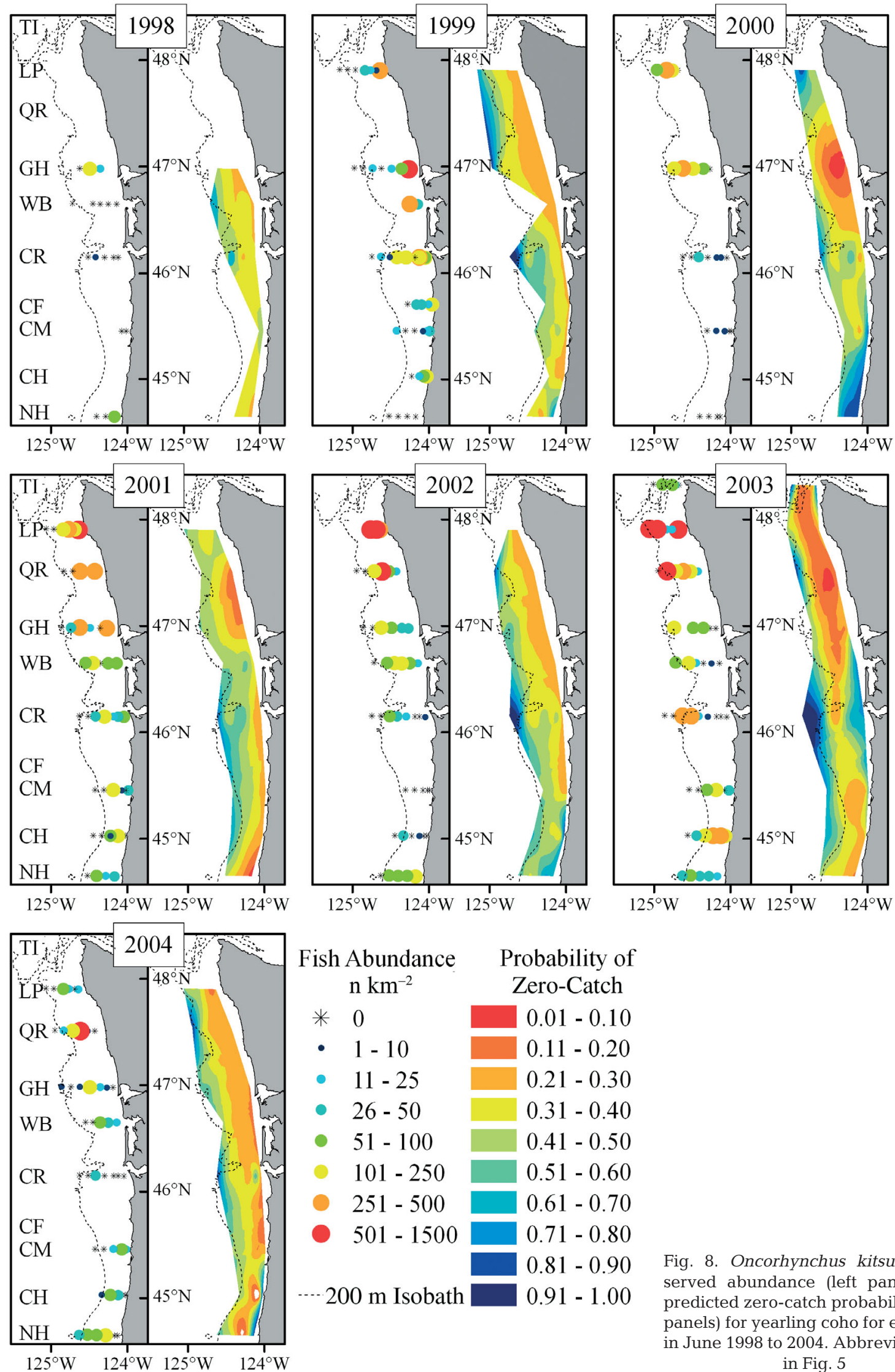

Fig. 8. Oncorhynchus kitsutch. Observed abundance (left panels) and predicted zero-catch probability (right panels) for yearling coho for each year in June 1998 to 2004. Abbreviations as in Fig. 5 

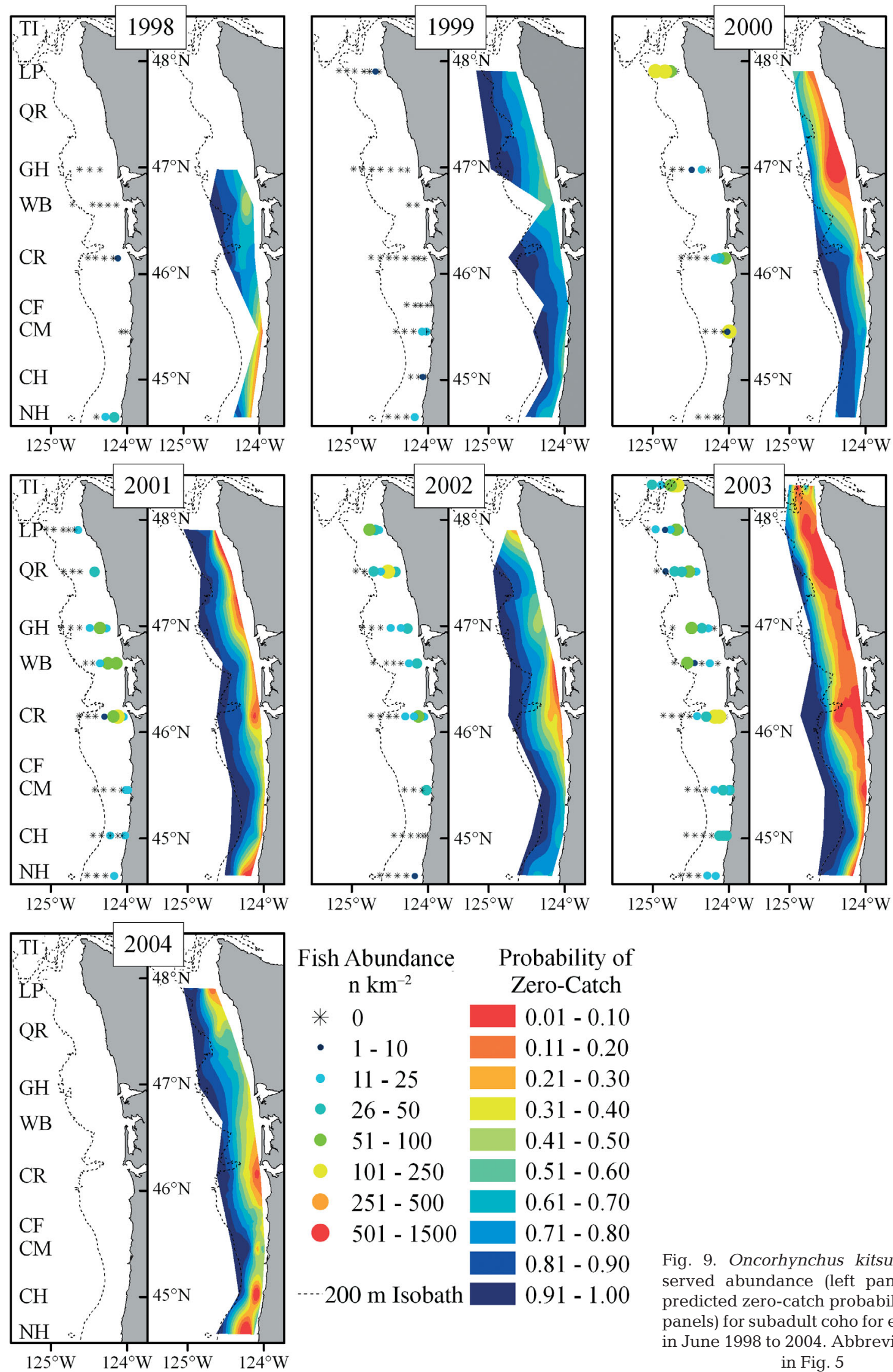

Fig. 9. Oncorhynchus kitsutch. Observed abundance (left panels) and predicted zero-catch probability (right panels) for subadult coho for each year in June 1998 to 2004. Abbreviations as in Fig. 5 


\section{Model validation}

The predicted zero-catch probabilities for all 3 life history stages of Chinook salmon (subyearling, yearling, and subadult) were generally higher than 0.5 for the entire study area in 2005 (Fig. 10). Zero-catch probabilities ranging from 0.3 to 0.5 occupied small nearshore areas around the Columbia River mouth and the LaPush transect. Predicted trends were consistent with field observations with 79 to $87 \%$ accuracy (Table 4), and a total of 19 subyearling Chinook, 12 yearling Chinook, and 0 subadult Chinook were caught in June 2005. Yearling coho were caught at
$32 \%$ of the sampled stations in 2005, and mean predicted zero-catch probability was 0.31 . Subadult coho were caught at $10 \%$ of the sampled stations, and mean predicted zero-catch probability was 0.73 .

Predicted zero-catch probabilities for subadult coho were generally higher than 0.5 for the entire area, except for a small nearshore area along the LaPush transect in 2005. The results were consistent with observed field samples with $89 \%$ accuracy (Table 4 ). For yearling coho, the predicted zero-catch probability generally ranged from 0.2 to 0.5 for most of the study area. When we divided the presence and absence at 0.5 zero-catch probability, only $34 \%$ of the modeled
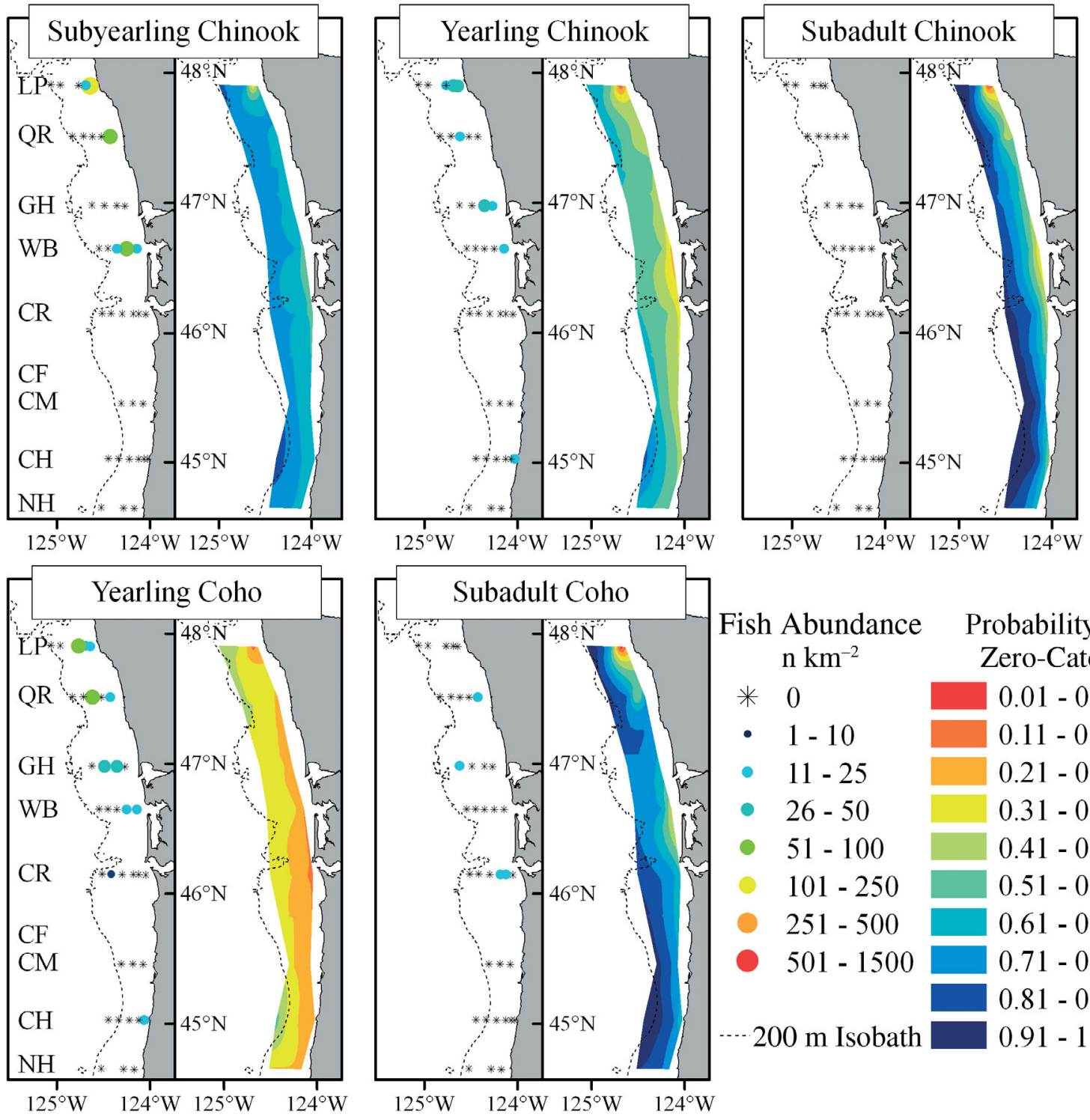

\section{Fish Abundance $\mathrm{n} \mathrm{km}{ }^{-2}$}

Probability of

* 0

- $1-10$

- $11-25$

- $26-50$

- $51-100$

$101-250$

$\begin{array}{ll} & 251-500 \\ & 501-1500\end{array}$ Zero-Catch

$$
\text { - } 101
$$

$0.01-0.10$

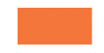

$0.11-0.20$

$0.21-0.30$

$0.31-0.40$

$0.41-0.50$

$0.51-0.60$

- $501-1500$

$0.61-0.70$

$200 \mathrm{~m}$ Isobath

$0.71-0.80$

$0.81-0.90$

…200 m Isobath $0.91-1.00$

Fig. 10. Oncorhynchus tshawytscha and O. kitsutch. Observed abundance (left panels) and predicted zero-catch probabilities (right panels) for subyearling Chinook, yearling Chinook, subadult Chinook, yearling coho, and subadult coho in June 2005 from predictive models based on data collected in June 1998 to 2004. Abbreviations as in Fig. 5 
Table 4. Oncorhynchus tshawytscha and O. kitsutch. Error matrices for the predicted presence/absence (divided at 0.5 zero-catch probability) versus observed presence/absence for all 5 life history stages

\begin{tabular}{|c|c|c|c|c|c|c|c|}
\hline \multirow{2}{*}{$\begin{array}{l}\text { Life history } \\
\text { stage }\end{array}$} & \multicolumn{3}{|c|}{ Observed absence } & \multicolumn{3}{|c|}{ - Observed presence } & \multirow{2}{*}{$\begin{array}{c}\text { Overall } \\
\text { model } \\
\text { accuracy }\end{array}$} \\
\hline & $\begin{array}{l}\text { Predicted } \\
\text { absence }\end{array}$ & $\begin{array}{c}\text { Predicted } \\
\text { presence }\end{array}$ & $\begin{array}{l}\text { Absence } \\
\text { accuracy }\end{array}$ & $\begin{array}{l}\text { Predicted } \\
\text { presence }\end{array}$ & $\begin{array}{l}\text { Predicted } \\
\text { absence }\end{array}$ & $\begin{array}{l}\text { Presence } \\
\text { accuracy }\end{array}$ & \\
\hline \multicolumn{8}{|l|}{ Chinook } \\
\hline Subyearling & 32 & 0 & $100 \%$ & 1 & 5 & $17 \%$ & $87 \%$ \\
\hline Yearling & 24 & 6 & $80 \%$ & 6 & 2 & $75 \%$ & $79 \%$ \\
\hline Subadult & 30 & 7 & $79 \%$ & 0 & 0 & Undefined $^{\mathrm{a}}$ & $79 \%{ }^{a}$ \\
\hline \multicolumn{8}{|l|}{ Coho } \\
\hline Yearling $^{\mathrm{b}}$ & 1 & 25 & $4 \%$ & 12 & 12 & $100 \%$ & $34 \%$ \\
\hline Subadult & 30 & 4 & $88 \%$ & 4 & 0 & $100 \%$ & $89 \%$ \\
\hline \multicolumn{8}{|c|}{$\begin{array}{l}\text { a The observed presence for subadult Chinook was consistent with the prediction from the selected model } \\
\text { bIf the predicted presence/absence for yearling coho is divided at } 0.25 \text { zero-catch probability, the overall model accuracy } \\
\text { increases to } 66 \%\end{array}$} \\
\hline
\end{tabular}

results were consistent with field observations (Table 4). However, when we divided presence and absence at 0.3 zero-catch probability, $66 \%$ of the modeled results were consistent with field observations. The lowest zero-catch probability in 2005 for yearling coho was 0.16 , and no noticeable areas with zero-catch probability less than 0.2 were identified in the interpolated model surface.

\section{DISCUSSION}

\section{Choice of habitat}

We demonstrated that logistic regression models developed in this study can be used to predict the size and location of suitable salmon habitat off the Washington and Oregon coast. Spatial autocorrelation for some independent variables (such as depth) may reduce the effective degrees of freedom in our analysis (i.e. samples lack independence). However, we only used significance tests to select models and classify the presence/absence of salmon, and the models were validated by independent samples (from 2005). Therefore, it is unlikely that spatial autocorrelation would change our results.

Water depth and chlorophyll a concentration were strongly related to habitat selection for all 5 life history stages, as indicated by nonparametric correlation and stepwise logistic regression. Surprisingly, the temperature effect was not always significant; stepwise logistic regression showed that temperature had significant effects on subyearling Chinook and yearling coho, and nonparametric correlation showed significant effects on yearling and subadult Chinook and subadult coho. Salinity did not appear in any of the selected models for all 5 life history stages.
Chlorophyll a concentration was related positively to Chinook and coho salmon presence. The inter-annual variation in habitat size for all 5 life history stages were consistent with variability in surface chlorophyll a derived from Sea-viewing Wide Field-of-view Sensor (SeaWiFS) satellite $8 \mathrm{~d}$ composite images, e.g. there were large areas with high chlorophyll a concentration in 2003 (Fig. 11). Comparing the predicted habitat patterns with SeaWiFS chlorophyll images, we found that both Chinook and coho salmon were not likely to occur (probability of absence $>0.5$ ) in areas with chlorophyll a concentration lower than $3 \mathrm{mg} \mathrm{m}^{-3}$. In 2003, there were large areas off Washington and the Columbia River mouth with chlorophyll a concentration higher than $10 \mathrm{mg} \mathrm{m}^{-3}$. In 2000, the SeaWiFS imagery did not have complete coverage of the study area due to cloud cover, but it indicated 2 high chlorophyll a regions located off the Columbia River mouth and the Washington coast. As a result, there was more utilized habitat area for subadult Chinook and subadult coho in 2000 and 2003 than in other years. Yearling Chinook and yearling coho had relatively large areas of utilized habitat (probability of absence $<0.5$ ) throughout the study period. In 2000 and 2003, we also found that there were a few habitat 'hotspots' (probability of absence <0.2) within the high chlorophyll a concentration areas for yearling Chinook and yearling coho at the nearshore stations of LaPush, Queets River, Grays Harbor, and Columbia River transects. Subyearling Chinook showed a similar pattern, with relatively large areas of utilized habitat in 2000 and 2003. A considerable body of literature has documented that marine resources are related to productivity hotspots (e.g. Olivar 1990, Solanki et al. 2001, Valavanis et al. 2004). Our study demonstrated that utilized habitats for Chinook and coho salmon were generally within or in the vicinity of high chlorophyll a concentration areas. 

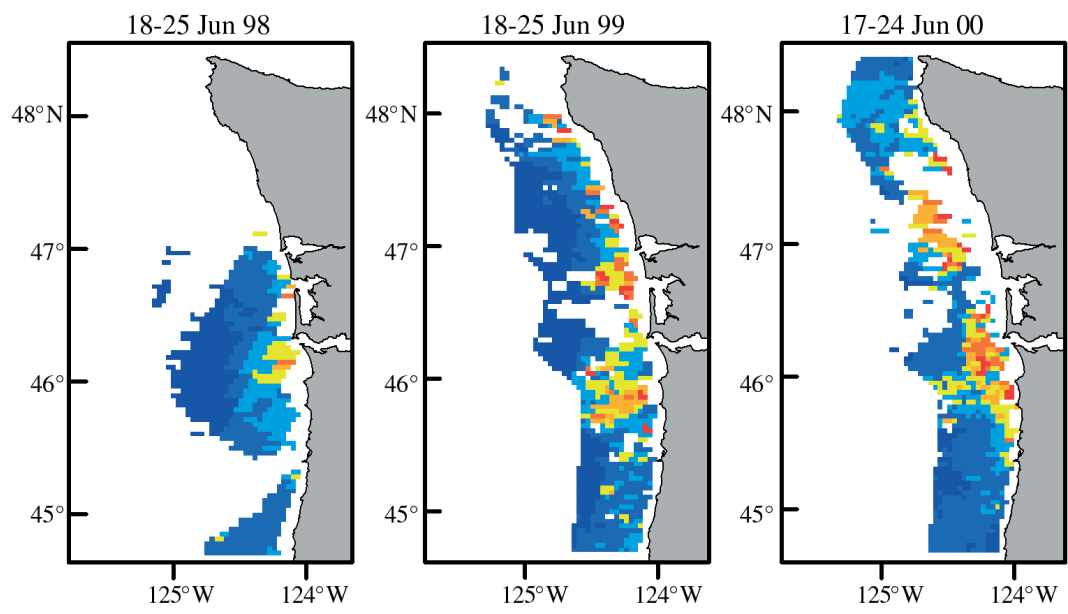

26 Jun-3 Jul 01
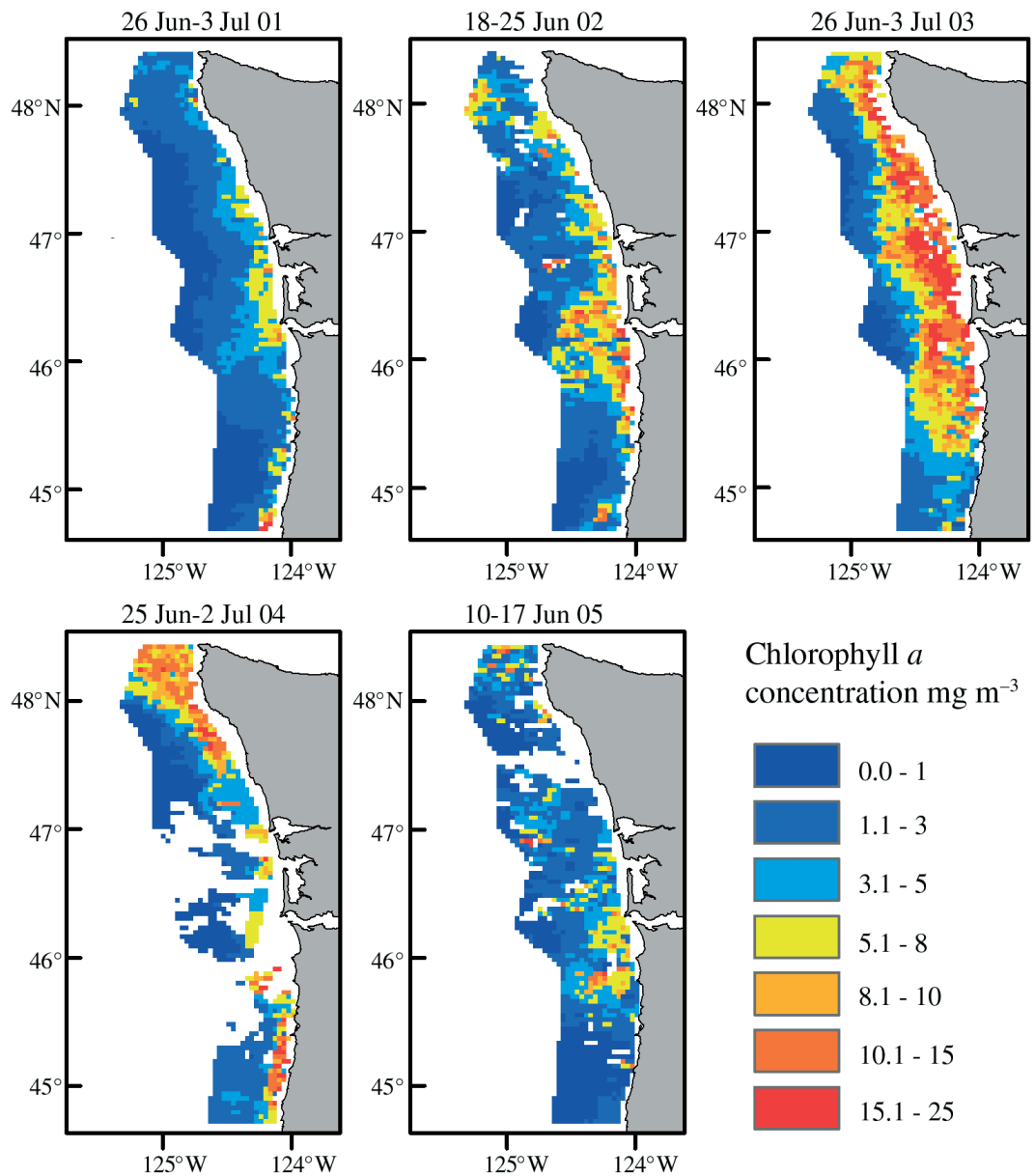

Chlorophyll $a$ concentration $\mathrm{mg} \mathrm{m}^{-3}$

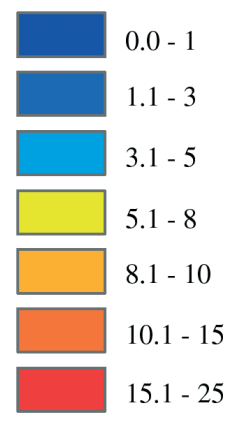

Fig. 11. Chlorophyll a concentrations from 8 d composite SeaWiFS imagery coincident with the majority of each June cruise in 1998 to 2005

$150 \mathrm{~m})$, although yearling Chinook and coho were distributed further offshore than subyearling and subadult Chinook and subadult coho. Of the 5 life history stages, yearling coho may distribute farther offshore on the basis of zerocatch probability.

Relationships between temperature and the presence of Chinook and coho were not as apparent as those for chlorophyll $a$ and depth, as indicated by both logistic regression and nonparametric regression analysis. In the logistic regression model, temperature was statistically significant for subyearling Chinook and yearling coho, but temperature did not exhibit a clear relationship with zero-catch probability as did chlorophyll $a$ and water depth. This suggests that temperature may not be the primary factor in defining salmon ocean habitat. Friedland et al. (2005) reported that Atlantic salmon growth appears to be both positively and negatively correlated with temperature conditions for post-smolts in the early marine phase. Hinke et al. (2004, 2005) found that even though Chinook salmon occurred primarily in 9 to $12^{\circ} \mathrm{C}$ water off Oregon and the northern California coast in the fall, environmental temperature variation did not necessarily mediate their growth and maturation. Besides that, most of the coastal waters off Washington and Oregon are within the optimum range for Chinook (Brodeur et al. 2005). As a result, temperature may not be a limiting factor in shaping salmon distribution in the area examined in this study.

Salinity was not a significant factor influencing the occurrence of all 5 life history stages as indicated by stepwise logistic regression. This result was surprising because salmon first enter the ocean at the Columbia River, and presumably spend some time in the plume adapting physiologically to the marine environment. One possible explanation

Water depth was positively related to the absence of the 5 life history stages. This is consistent with the accepted tenet that both Chinook and coho live almost exclusively in coastal waters (Beamish et al. 2005). Our study showed that all 5 life history stages were distributed within $200 \mathrm{~m}$ water depth (and mostly within is that juvenile salmon had been in the ocean for a few weeks prior to our surveys and had already adapted to the high salinity environment.

The distributions of Chinook and coho salmon are influenced by environmental variables, food, and predation. Previous studies investigated relationships 
between marine survival and ocean production and temperature, upwelling, and other ocean conditions (Mantua et al. 1997, Logerwell et al. 2003). However, habitat selection by Chinook and coho salmon with respect to ocean conditions is limited, but see Hinke et al. (2004, 2005). Although chlorophyll a concentration may not be directly related to salmon habitat selection, it might provide an index of the high biomass associated with preferred food sources of salmon. Consequently, knowledge of salmon prey distributions are necessary to explain this bottom-up control mechanism. In addition, regions of high chlorophyll a have higher turbidity, a condition that could decrease the probability of a salmon being eaten, depending on the relative sensory capacities of salmon versus its potential predators.

\section{Spatial variation: linkages with local physical and biological environments}

The common spatial characteristics for all 5 life history stages included: (1) used habitat occurred in shallow coastal waters, and (2) there were more areas of used habitat off the Washington coast and the Columbia River mouth. These patterns were consistent throughout the entire study period and were also consistent with our observed abundances.

The cross-shelf distribution pattern we observed was consistent with studies on other trophic levels in the same study area. Phytoplankton decreased exponentially with water depth. Copepod biomass also declined exponentially across the continental shelf (Peterson et al. 1979, Lamb \& Peterson 2005). However, different life history stages of Chinook and coho salmon appeared to utilize different zones in the shallow-water region. For example, subadult Chinook were confined to coastal waters less than $100 \mathrm{~m}$ deep, while subyearling and yearling Chinook extended their habitat to relatively deeper water. Coho salmon showed the same coastal pattern, but also selected habitats that extended to the edge of the continental shelf. The reasons for different utilization of the coastal zone by these 2 species remain unclear.

The large alongshore differences in Chinook and coho salmon habitat between the Washington and Oregon coasts may be caused by variations in local physical and biological conditions, such as a wider shallow nearshore region and higher chlorophyll a concentration off Washington than off Oregon (Hickey \& Banas 2003). Another potential cause for this alongshore distribution may relate to salmon hatchery location; more hatcheries are located in the north (Washington and the Columbia River) and fewer in the south (Oregon and California). Moreover, the northward movement of Pacific salmon has been well established (Pearcy \& Fisher 1988), and may be a latent factor responsible for the difference between the Oregon and Washington coast. However, salmon are not evenly distributed off the Washington coast, which suggests that other environmental factors are operating in coastal waters that contribute to uneven distribution patterns. The selected logistic regression models not only showed the difference in used habitat between the Oregon and Washington coast, but also the unequal distribution of salmon within Washington coastal waters. Areas of high probability of salmonid presence were generally located within the high chlorophyll a regions as indicated by $8 \mathrm{~d}$ composite SeaWiFS imagery (Fig. 11). This indicates chlorophyll a concentration is a good predictor variable for salmon distribution.

\section{Temporal variations in the context of large scale climate variations}

The size of used habitat varied substantially across the study period for all 5 life history stages. Large areas with high probability of salmonid presence $(>0.8)$ occurred in 2003 and 2000, and progressively decreased through 2001, 2002, and 2004. In 1998 and 1999, most of the study area had a probability of salmonid presence lower than 0.8 . In the first year of study, a strong El Niño occurred, followed by a major La Niña in 1999 (Peterson \& Schwing 2003). Ocean conditions during 2000 to 2002 remained similar to 1999 as indicated by the PDO index (http://jisao.washington.edu/pdo/ PDO.latest), but in 2003 through 2005, a positive PDO index occurred, indicating warm ocean conditions. Temporal variation of used habitat area was not consistent with the PDO index, such that 2003 was a warm year, but the size of used habitat was larger than in other years. Temporal variation of used habitat appeared to be consistent with changes in chlorophyll concentration as indicated by SeaWiFS satellite images (Fig. 11). At the same time, variations in abundance were observed at higher trophic levels, including zooplankton and pelagic nekton (Pearcy 2002, Peterson et al. 2002, Keister et al. 2005), but it remains unclear how these changes in zooplankton and nekton community influence salmon habitat selection.

\section{CONCLUSIONS}

Chlorophyll a concentration was an important factor in defining suitable salmon habitat. We found that high probability of Chinook and coho salmon presence was associated with areas of high chlorophyll a concentra- 
tion. We showed the potential use of satellite imagery (SeaWiFS and Coastal Zone Color Scanner, CZCS) in forecasting and hindcasting suitable salmon habitat and retrieving historical information related to spatial and temporal variations in habitat used by Pacific salmon. As a result, it could explain variability in salmon production from a habitat perspective and enhance our understanding of how ocean conditions influence salmon production.

Water depth was an important factor in defining salmon habitat and reflected the inshore/offshore trend for Chinook and coho salmon, as well as zooplankton. Chinook and coho salmon were more aggregated in shallow coastal waters. There were differences between different species and life history stages, such that subyearling and subadult Chinook and subadult coho were closer to shore than yearling Chinook and yearling coho. Temperature was not as important as chlorophyll and water depth in defining used habitat, and only had significant effects on the distributions of subyearling Chinook and yearling coho.

This study demonstrates that the location and size of suitable salmon habitat exhibit large spatiotemporal variation. Larger areas of suitable Chinook salmon habitat occurred in 2000 and 2003, followed by 2001, 2002, and 2004. Coho salmon also had large areas of used habitat in 2000 and 2003, followed by 2001, 2004, and 2002. This provides the potential to understand the temporal variation in salmon production in terms of used habitat, a topic we intend to pursue.

Acknowledgements. This synthesis research was supported by US GLOBEC/National Oceanic Atmospheric Administration, and data collection was funded by Bonneville Power Administration. R.E.R. was supported by award OCE-0353083 from the National Science Foundation. We thank the many people who contributed greatly to the collection and processing of data: S. Hinton, C. Bucher, C. Morgan, B. Beckman, E. Daly, J. Zamon, T. Guy, and L. Weitkamp. We are especially indebted to our database team: C. Morgan, C. Bucher, and S. Hinton. A. Thomas and P. Brickley graciously provided us with the fully processed SeaWiFS composite imagery. We thank other members of our team for discussion and comments: E. Casillas, R. Brodeur, B. Emmett, T. Wainwright, B. Beckman, and K. Hunter. Use of trade names does not imply endorsement by the National Marine Fisheries Services, NOAA.

\section{LITERATURE CITED}

Arar EJ, Collins GB (1997) In vitro determination of chlorophyll $a$ and pheophytin a in marine and freshwater algae by fluorescence. USEPA, Cincinnati, $\mathrm{OH}$

Beamish RJ, Mahnken C (2001) A critical size and period hypothesis to explain natural regulation of salmon abundance and the linkage to climate and climate change. Prog Oceanogr 49:423-437

Beamish RJ, McFarlane GA, King JR (2005) Migratory patterns of pelagic fishes and possible linkages between open ocean and coastal ecosystems off the Pacific coast of North America. Deep-Sea Res II 52:739-755

Bradford, MJ (1995) Comparative review of Pacific salmon survival rates. Can J Fish Aquat Sci 52:1327-1338

Brodeur RD, Fisher JP, Teel DJ, Emmett RL, Casillas E, Miller TW (2004) Juvenile salmonid distribution, growth, condition, origin, and environmental and species associations in the Northern California Current. Fish Bull 102:25-46

Brodeur RD, Fisher JP, Emmett RL, Morgan CA, Casillas E (2005) Species composition and community structure of pelagic nekton off Oregon and Washington under variable oceanographic conditions. Mar Ecol Prog Ser 298:41-57

Cole J, Villacastin C (2000) Sea surface temperature variability in the northern Benguela upwelling system, and implications for fisheries research. Int J Remote Sens 21:1597-1617

Fisher JP, Pearcy WG (1988) Growth of juvenile coho salmon (Oncorhynchus kisutch) off Oregon and Washington, USA, in years of differing coastal upwelling. Can J Fish Aquat Sci 45:1036-1044

Francis RC, Hare SR (1994) Decadal-scale regime shifts in the large marine ecosystems of the North-east Pacific: a case for historical science. Fish Oceanogr 3:279-291

Friedland KD (1998) Ocean climate influences on critical Atlantic salmon (Salmo salar) life history events. Can J Fish Aquat Sci 55:119-130

Friedland KD, Chaput G, MacLean JC (2005) The emerging role of climate in post-smolt growth of Atlantic salmon. ICES J Mar Sci 62:1338-1349

Hickey BM, Banas NS (2003) Oceanography of the US Pacific northwest coastal ocean and estuaries with application to coastal ecology. Estuaries 26:1010-1031

Hinch SG, Healey MC, Diewert RE, Thomson KA, Hourston R, Henderson MA, Juanes F (1995) Potential effects of climate change on marine growth and survival of Fraser River sockeye salmon. Can J Fish Aquat Sci 52:2651-2659

Hinke JT, Watters GM, Boehlert GW, Zedonis P (2004) Ocean habitat use in autumn by Chinook salmon in coastal waters of Oregon and California. Mar Ecol Prog Ser 285:181-192.

Hinke JT, Foley DG, Wilson C, Watters GM (2005). Persistent habitat use by Chinook salmon Oncorhynchus tshawytscha in the coastal ocean. Mar Ecol Prog Ser 304:207-220

Hosmer DW, Lemeshow S, Klar J (1988) Goodness-of-fit testing for the logistic-regression model when the estimated probabilities are small. Biometrical J 30:911-924

Keister JE, Johnson TB, Morgan CA, Peterson WT (2005) Biological indicators of the timing and direction of warmwater advection during the 1997/1998 El Niño off the central Oregon coast, USA. Mar Ecol Prog Ser 295:43-48

Knapp RA, Preisler HK (1999) Is it possible to predict habitat use by spawning salmonids? A test using California golden trout (Oncorhynchus mykiss aguabonita). Can J Fish Aquat Sci 56:1576-1584

Lamb J, Peterson WT (2005) Ecological zonation of zooplankton in the COAST study region off central Oregon in June and August 2001 with consideration of retention mechanisms. J Geophys Res 110:C10S15, doi:10.1029/ 2004JC002520

Logerwell EA, Mantua N, Lawson PW, Francis RC, Agostini VN (2003) Tracking environmental processes in the coastal zone for understanding and predicting Oregon coho (Oncorhynchus kisutch) marine survival. Fish Oceanogr 12: $554-568$

Mantua NJ, Hare SR, Zhang Y, Wallace JM, Francis RC (1997) A Pacific interdecadal climate oscillation with impacts on salmon production. Bull Am Meteorol Soc 78:1069-1079

McHugh P, Budy P (2004) Patterns of spawning habitat selection and suitability for two populations of spring Chinook 
salmon, with an evaluation of generic versus site-specific suitability criteria. Trans Am Fish Soc 133:89-97

Olivar MP (1990) Spatial patterns of ichthyoplankton distribution in relation to hydrographic features in the northern Benguela region. Mar Biol 106:39-48

Pearcy WG (1992) Ocean ecology of North Pacific salmonids. Washington Sea Grant Program, University of Washington Press, Seattle, WA

Pearcy WG (2002) Marine nekton off Oregon and the 1997-98 El Niño. Prog Oceanogr 54:399-403

Pearcy WG, Fisher JP (1988) Migrations of coho salmon, Oncorhynchus kisutch, during their first summer in the ocean. Fish Bull 86:173-195

Peterson WT, Schwing FB (2003) A new climate regime in northeast pacific ecosystems. Geophys Res Lett 30:1896, doi:10.1029/2003GL017528

Peterson WT, Miller CB, Hutchinson A (1979) Zonation and maintenance of copepod populations in the Oregon upwelling zone. Deep-Sea Res 26:467-494

Peterson WT, Keister JE, Feinberg LR (2002) The effects of the 1997-99 El Niño/La Niña events on hydrography and zoo-

Editorial responsibility: Howard Browman (Associate Editorin-Chief), Storebø, Norway plankton off the central Oregon coast. Prog Oceanogr 54: 381-398

Shiomoto A, Tadokoro K, Nagasawa K, Ishida Y (1997) Trophic relations in the subarctic North Pacific ecosystem: possible feeding effect from pink salmon. Mar Ecol Prog Ser 150: $75-85$

Solanki HU, Dwivedi RM, Nayak SR (2001) Synergistic analysis of SeaWiFS chlorophyll concentration and NOAAAVHRR SST features for exploring marine living resources. Int J Remote Sens 22:3877-3882

Turdeon K, Rodriguez MA (2005) Predicting microhabitat selection in juvenile Atlantic salmon Salmo salar by the use of logistic regression and classification trees. Freshw Biol 50:539-551

Valavanis VD, Kapantagakis A, Katara I, Palialexis A (2004) Critical regions: a GIS-based model of marine productivity hotspots. Aquat Sci 66:139-148

Welch DW, Ishida Y, Nagasawa K (1998) Thermal limits and ocean migrations of sockeye salmon (Oncorhynchus nerka): long-term consequences of global warming. Can J Fish Aquat Sci 55:937-948

Submitted: May 5, 2006; Accepted: October 10, 2006 Proofs received from author(s): April 16, 2007 